\title{
Penerapan metode praktikum berbasis bahan alam dalam pembelajaran kimia untuk meningkatkan hasil belajar siswa pada materi reaksi redoks
}

\author{
Loriana Tiak $^{* a}$, Djefri Tani ${ }^{,}$, Joice D. S. Caroles ${ }^{a}$ \\ a Universitgs Negeri Manado, Tondano, 95618, Indonesia
}

\begin{tabular}{|c|c|}
\hline INFO ARTIKEL & A B S T R A C T \\
\hline Diterima 04 Mei 2019 & The purpose of this study was to determine the improvement in learning outcomes of \\
\hline Disetujui 13 Juni 2019 & $\begin{array}{l}\text { class X students in East Halmahera } 9 \text { High School on redox reaction topic by using } \\
\text { natural product praticum methods in chemistry learning. This research is a pre- }\end{array}$ \\
\hline Key word: & experimental study with a One Group Pretest-Posttest Design. The population and \\
\hline $\begin{array}{l}\text { Learning Outcaomes, Practicum } \\
\text { on Natural Product, Redox }\end{array}$ & $\begin{array}{l}\text { sample are taken all students of class } X \text { with a total number of students of } 20 \text { people. } \\
\text { The collected data is processed from the results of the pretes-posttest. Data were } \\
\text { analyzed using the formula t-test the research hypothesis and obtained tcount>t table }\end{array}$ \\
\hline $\begin{array}{l}\text { Kata kunci: } \\
\text { Hasil belajar, praktikum bahan } \\
\text { alam, redoks. }\end{array}$ & $\begin{array}{l}(19.49>2.10) \text {. The results show that the average posttest value was greater than the } \\
\text { average value of the pretest, so it can be concluded that student learning outcomes } \\
\text { provided with natural product practicum methods influence student learning } \\
\text { outcomes. }\end{array}$ \\
\hline
\end{tabular}

*e-mail:loritiak@gmail.com ${ }^{*}$ Telp:

\begin{abstract}
ABSTRAK
Tujuan penelitian ini adalah untuk mengetahui peningkatan hasil belajar siswa kelas X di SMA N 9 Halmahera Timur pada materi reaksi redoks dengan menggunakan metode praktikum berbasis bahan alam dalam pembelajaran kimia. Penelitian ini adalah penelitian pra-eksperimen dengan rancangan penelitian One Group Pretest-Posttest Design. Populasi dan sampel yang diambil adalah seluruh siswa kelas $X$ dengan total jumlah siswa 20 orang. Data yang dikumpulkan diolah dari hasil tes awal dan akhir pembelajaran. Data dianalisis dengan menggunakan rumus t-test untuk menguji hipotesis penelitian dan diperoleh thitung $>$ tabel $(19.49>2.10)$. Hasil penelitian menunjukkan bahwa nilai rata-rata posttest lebih besar dari nilai rata-rata pretest, sehingga dapat disimpulkan bahwa hasil belajar siswa yang diberikan dengan metode praktikum berbasis bahan alam berpengaruh terhadap hasil belajar siswa.
\end{abstract}

\section{Pendahuluan}

Pembelajaran kimia yang dilaksanakan di sekolah pada umumnya bertujuan untuk mencapai tujuan pembelajaran. Tujuan pembelajaran ini mengharuskan siswa siap menyerap materi yang disampaikan oleh guru. Setiap proses pembelajaran pada pelajaran kimia yang diberikan akan melibatkan cara berpikir (kognitif), terampil dalam praktikum (psikomotor), dan berperilaku (afektif). Masalah yang sering dijumpai dalam dunia pendidikan yaitu pada setiap proses pembelajaran kimia hanya digunakan metode ceramah. Hal ini mengakibatkan siswa dalam mengikuti proses pembelajaran kurang berperan aktif dan juga kurang terampil dalam menemukan pengetahuan sendiri, sehingga kesulitan dalam menangkap materi yang diberikan. Oleh karena itu diperlukan suatu metode yang aktif, inovatif, kreatif, dan menyenangkan bagi siswa untuk belajar. Salah satu metode yang melibatkan siswa secara aktif dan kreatif yaitu metode praktikum.

Metode praktikum dapat meningkatkan pemahaman siswa, dan menumbuhkan sikap ilmiah seperti peka atau kritis terhadap lingkungan, rasa ingin tahu, dan objektivitas siswa [1]. Tujuan penelitian ini yaitu untuk 
mengetahui peningkatan hasil belajar siswa kelas X di SMA N 9 Halmahera Timur pada materi reaksi Redoks dengan menggunakan metode praktikum berbasis bahan alam dalam pembelajaran kimia. Observasi awal yang telah dilakukan di SMA N 9 Halmahera Timur bahwa proses dalam mengajar kimia hanya menggunakan metode ceramah tanpa disertai dengan praktikum. Hal ini disebabkan minimnya alat-alat serta bahan yang tersedia di laboratorium sekolah. Untuk menghadapi kendala di atas maka diperlukan suatu metode alternatif yang dapat menggantikan bahanbahan serta alat-alat praktikum yang belum tersedia di laboratorium.

Salah satu metode alternatif yang dapat dilakukan yaitu dengan menggunakan praktikum berbasis bahan alam agar dapat mempermudah dalam melakukan kegiatan praktikum. Praktikum berbasis bahan alam merupakan percobaan langsung dan sederhana dengan memanfaatkan bahan-bahan yang dapat ditemukan dengan mudah di alam sekitar lingkungan sekolah dengan harga yang terjangkau.

Praktikum berbasis bahan alam dapat dilakukan dengan mudah walaupun tanpa alat dan bahan praktikum sebagaimana di laboratorium. Pemanfaatan lingkungan sebagai pelaksanaan praktikum dan bahan praktikum merupakan kemampuan bagi guru mengembangkan kemampuan berpikir ilmiah dalam mengembangkan metode pembelajaran, di mana ia mampu melihat lingkungan sebagai inspirasi yang diamati dan dapat dibawa ke ruang kelas [1].

\section{Metode}

Jenis penelitian yang digunakan dalam penelitian ini adalah penelitian Pre-eksperimen. Desain penelitian ini dapat dilihat pada Tabel 1.

Tabel 1. One Group Pretest Posttest Design

\begin{tabular}{ccc}
\hline Pretest & Treatment & Pot-test \\
\hline $\mathrm{O}_{1}$ & $\mathrm{X}$ & $\mathrm{O}_{2}$
\end{tabular}

Penelitian ini dilaksanakan di SMA N 9 Halmahera Timur, Desa Dorosago, Kecamatan Maba Utara, Kabupaten Halmahera Timur, pada semester genap tahun ajaran 2018/2019 tepatnya di bulan Februari. Populasi dan sampel pada penelitian ini yaitu seluruh siswa kelas X IPA SMA N 9 Halmahera Timur sebanyak 20 orang.

Penelitian ini dilaksanakan menggunakan prosedur penelitian yang alur pelaksanannya terdiri dari 3 tahapan kegiatan, yakni: a) tahap persiapan, b) tahap pelaksanaan, dan c) tahap akhir. Data penelitian dikumpulkan melalui hasil pretest dan posttest untuk mengetahui hasil belajar siswa. Instrument penelitian yang digunakan adalah RPP, penuntun praktikum dan soal dalam bentuk essay.

\section{Uji validitas dan reliabilitas}

Uji validitas intrumen menggunakan rumus Productt Moment dari Karl Pearson, sedangkan uji reliabilitas menggunakan rumus

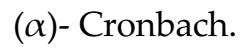

\section{Analisis Data Uji t}

Rumus uji t adalah salah satu teknik analisis data yang digunakan dalam desain penelitian pra eksperimen one grup pretest posttest design [2]. Rumus t-tes bertujuan untuk mengetahui signifikan perbedaan 2 (dua) mean sampel.

\section{Hasil dan Pembahasan}

Penelitian ini dilaksanakan di SMA N 9 Halmahera Timur pada kelas $X$ yang dijadikan sampel dengan jumlah siswa 20 orang. Data hasil penelitian diperoleh dari hasil pretest dan hasil posttest. Hasil pretest dan posttest dapat dilihat pada Gambar 1.

\section{Data Hasil Pre- test}

Berdasarkan hasil perhitungan data penelitian tes kognitif pretest dari 20 siswa yang dijadikan sampel penelitian diperoleh nilai terendah 0 dan nilai tertinggi 60 . Skor rata-rata yang diperoleh yaitu sebesar 24.25. Siswa yang mencapai KKM 1 orang dan siswa yang tidak mencapai KKM 19 orang.

\section{Data Hasil Posttest}

Berdasarkan hasil perhitungan data penelitian kognitif posttest setelah diterapkan metode praktikum yaitu nilai terendah 50 dan nilai tertinggi 90 . Skor rata-rata yang diperoleh siswa yaitu sebesar 71.75. Pada hasil nilai posttest terdapat satu orang siswa yang tidak mencapai KKM, akan tetapi terdapat 
peningkatan hasil belajar pada siswa tersebut.

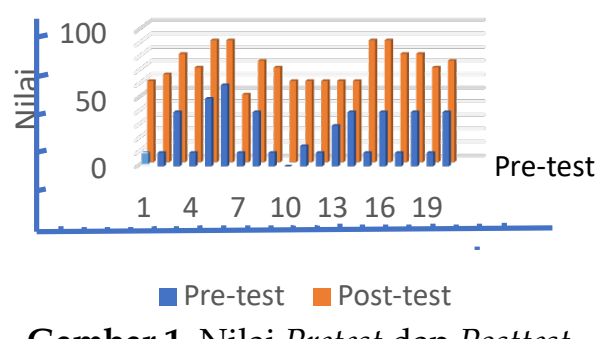

Gambar 1. Nilai Pretest dan Posttest

\section{Analisis Uji Instrumen Tes Uji Validasi}

Uji validasi dalam penelitian ini menggunakan rumus Productt Moment dari Karl Person. Penelitian ini validasi instrumen dilakukan pada siswa kelas XI IPA di SMA N 9 Halmahera Timur. Berdasarkan hasil validasi instrumen dari 10 soal yang diberikan kepada siswa, terdapat 8 soal dikatakan valid dan 2 soal tidak valid. Maka dari itu, instrumen termasuk valid dan layak digunakan.

\section{Uji Reliabilitas}

Hasil analisis reliabilitas menggunakan rumus alfa cronbach. Rata-rata hasil reliabilitas dari setiap butir soal adalah 0.87 termasuk kriteria sangat tinggi. Instrumen yang digunakan reliabel.

\section{Analisis Data Penelitian}

Uji $t$ dilakukan bertujuan untuk mengetahui peningkatan hasil belajar siswa pada materi reaksi Redoks dengan menggunakan metode praktikum. Pada penelitian ini uji t yang digunakan yaitu rumus paired t-test. Kriteria pengujian untuk rumus uji $\mathrm{t}$ adalah jika hipotesis alternatif $\left(\mathrm{H}_{\mathrm{a}}\right)$ diterima dan hipotesis nihil $\left(\mathrm{H}_{0}\right)$ ditolak berarti terdapat peningkatan hasil belajar siswa pada materi reaksi Redoks setelah diterapkan metode praktikum berbasis bahan alam, sedangkan jika hipotesis alternatif $\left(\mathrm{H}_{\mathrm{a}}\right)$ di tolak dan hipotesis nihil $\left(\mathrm{H}_{0}\right)$ diterima berarti tidak terdapat peningkatan hasil belajar siswa pada materi reaksi Redoks setelah diterapkan metode praktikum berbasis bahan alam. Pada data nilai pretest dan nilai posttest dilakukan uji hipotesis dengan mengunakan uji t.

Pada hasil pengujian hipotesis diperoleh nilai thitung $=19,49$ sedangkan nilai tabel pada taraf signifikansi $\alpha=0,05$, dengan derajat kebebasan 18 adalah 2,10. Berdasarkan hasil tersebut nilai thitung > dari nilai ttabel, maka $\mathrm{H}_{a}$ diterima, sehingga dapat disimpulkan bahwa terdapat peningkatan hasil belajar siswa pada materi reaksi Redoks dengan menggunakan metode praktikum dalam pembelajaran kimia.

\section{Pembahasan}

Praktikum berbasis bahan alam dapat dilakukan dengan mudah walaupun tanpa alat dan bahan yang tersedia di laboratorium, sehingga sangat cocok dengan kondisi sekolah di SMA N 9 Halmahera Timur. Peneliti memanfaatkan lingkungan di sekitar sekolah SMA N 9 Halmahera Timur untuk membuat siswa berpikir bahwa melakukan suatu kegiatan praktikum kimia tidak selalu menggunakan zat-zat kimia, tetapi dapat memanfaatkan alam sekitar sebagai bahan praktikum. Alat dan bahan yang digunakan dalam kegiatan praktikum tidak membuat sulit bagi siswa untuk menemukannya karena bahan tersebut dapat ditemukan di sekitar sekolah maupun tempat tinggal masing-masing siswa.

Pada penelitian ini metode yang digunakan sangat berdampak bagi siswa, karena sangat jarang pembelajaran kimia di sekolah tersebut disertai dengan metode praktikum. Hal ini membuat siswa lebih bersemangat untuk mempelajari materi kimia. Kegiatan praktikum membuat siswa lebih aktif dalam aktivitas pembelajaran kimia, hal ini dapat dibuktikan melalui hasil belajar siswa. Penerapan metode praktikum yang dilaksanakan bertujuan untuk mengetahui peningkatan hasil belajar siswa pada materi reaksi Redoks, dimana adanya peningkatan hasil belajar siswa tersebut sesudah pembelajaran yang disertai dengan pelaksanaan praktikum.

Penerapan metode praktikum pada proses pembelajaran kimia melibatkan cara berpikir (kognitif) terbukti bahwa terdapat peningkatan kognitif siswa sebelum dan sesudah diberikan perlakuan. Metode praktikum juga melibatkan keterampilan dalam praktikum (psikomotor), hal ini terbukti dalam proses praktikum siswa terampil mengikuti prosedur praktikum. Selain itu metode praktikum juga berkaitan dengan berperilaku (afektif) yang diperoleh dari minat 
dan motivasi dalam mempelajari materi kimia. Penelitian ini sejalan dengan penelitianpenelitian yang terdahulu yang pernah dilakukan oleh Suryadi [1], Silalahi [3] dan Fitri (2017) dengan menggunakan metode praktikum dapat meningkatkan hasil belajar siswa dan aktivitas belajar siswa.

\section{Ucapan terimakasih}

Disampaikan banyak terima kasih kepada seluruh dosen di Jurusan Kimia Fakultas Matematika dan Ilmu Pengetahuan Alam Universitas Negeri Manado dan juga SMA N 9 Halmahera Timur yang berperan penting dalam pelaksanaan penelitian ini.

\section{Kesimpulan}

Berdasarkan data hasil penelitian dan analisis data yang telah diuraikan, maka dapat disimpulkan bahwa penerapan metode praktikum berbasis bahan alam dapat meningkatkan hasil belajar siswa.

\section{Daftar Pustaka}

1. Suryadi, L. Implementasi Metode Praktikum Berbasis Lingkungan Pada Materi Reaksi Kimia Siswa Kelas X Madrasah Aliyah AL Jihad Nanga Tepuai Kapuas Hulu. Al-Razi jurnal Ilmiah, 2017, Volume 5, pp. 54-65, DOI.

2. Arikunto. Dasar-Dasar Evaluasi Pendidikan. Bumi Aksara : Jakarta, Indonesia, 2006. ISBN.

3. Silalahi, R. R. Meningkatkan Penguasaan Materi Larutan Asam Basa Dengan Metode Eksperimen Berwawasan Lingkungan Siswa Kelas XI IPA Di SMA N 1 Tebing Tinggi. Jurnal Handayani, 2016, Volume 5, pp. 144152.

4. Fitri, A. Implementasi Metode Praktikum Berbasis Lingkungan Pada Materi Laju Reaksi XI SMA Dayah Terpadu Inshafuddin Banda Aceh. jurnal ilmiah mahasiswa pendidikan kimia (JIMPK), 2018. Vol 3, pp. 48-55. 